\title{
MANAJEMEN LABA DAN KINERJA KEUANGAN PERUSAHAAN PENGAKUISISI SEBELUM DAN SETELAH AKUISISI
}

\author{
Lu' lu' il Maknuun, SE., MM. \\ E-mail: luluilmaknuun92@google.com
}

\begin{abstract}
The purpose of this study is to obtain empirical evidence of whether the acquirers perform earnings management prior to implementation of the acquisition. This type of research is a comparative study which compares the financial performance before and after the company making acquisitions. Analysis of financial performance is using financial ratios, including profitability, and activity. The results of data analysis shows that there was no indication of earnings management before the acquisitions con-ducted by the acquirer with Increasing income accruals. Furthermore, the company's financial perfor-mance as measured by the ratio of total asset turnover, net profit margin, returns on assets after the acquisition has a difference in the negative direction. The conclusion is that the acquirers before the acquisition are not convicted of earnings management with increasing income accrual. Acquirer's fi-nancial performance before and after the acquisitions have a difference, but the condition of the company is in sound condition.
\end{abstract}

Keywords: Acquisitions, earnings management, financial performanc

\section{PENDAHULUAN}

Persaingan usaha di antara perusahaanperusahaan yang semakin tajam menuntut perusahaan untuk selalu mengembangkan strategi perusahaan supaya dapat mempertahankan eksistensinya. Strategi yang dapat dilakukan oleh perusahaan salah satunya adalah melalui penggabungan usaha. Penggabungan usaha merupakan penyatuan dua atau lebih perusahaan yang terpisah menjadi satu entitas ekonomi karena satu perusahaan menyatu dengan perusahaan lain atau memperoleh kendali atas aktiva dan operasi perusahaan lain. Penggabungan usaha pada umumnya dilakukan dalam bentuk merger, akuisisi, dan konsolidasi. Akuisisi merupakan cara pengembangan dan pertumbuhan perusahaan, Akuisisi merupakan alternatif investasi modal per-tumbuhan secara internal. Perusahaan lebih me-nyukai pertumbuhan eksternal melalui merger dan akuisisi dibanding pertumbuhan internal.

Aktivitas akuisisi semakin meningkat seiring dengan intensnya perkembangan ekonomi yang makin mengglobal. Setiap tahunnya, Di Indonesia menunjukkan skala peningkatan yang cukup signifikan dari tahun ke tahun. Fenomena akuisisi sendiri sudah menjadi hal yang popular di Negara-negara maju seperti

Amerika Serikat, Kanada dan Eropa Barat, seperti contoh terbaru di Indonesia yaitu akuisisi Unilever atas Sara Lee Company, Aqua diakuisisi oleh Danone, Pizza Hut oleh Coca-Cola, dan lainlain. Namun di balik peristiwa akuisisi muncul lah berbagai kontroversi. Diantara kontroversi tersebut misalnya dilakukan rekayasa menghindari pajak, menggelembungkan nilai aset perusahaan dan mengurus manajemen perusahaan yang dikuasai.

Dalam pelaksanaan akuisisi terdapat suatu kondisi yang mendukung tindakan manajemen laba yang dilakukan oleh perusahaan pengakuisisi dimana perusahaan pengakuisisi ingin melakukan akuisisi dengan cara pembayaran lewat saham. Pihak manajemen perusahaan pengakuisisi cenderung berusaha untuk meningkatkan nilai laba perusahaan-nya dengan tujuan ingin menunjukkan earning power perusahaan dan dapat menarik minat perusahaan target untuk melakukan akuisisi juga untuk meningkatkan harga saham perusahaannya.

Manajemen laba merupakan campur tangan manajemen dalam proses penyusunan laporan keuangan eksternal guna mencapai tingkat laba ter- 
tentu dengan tujuan untuk menguntungkan dirinya sendiri. Peluang untuk mencapai laba tersebut timbul karena metode akuntansi memberikan peluang bagi manajemen untuk mencatat suatu fakta tertentu dengan cara yang berbeda dan peluang bagi manajemen untuk melibatkan subyektivitas dalam menyusun estimasi (Hadri dan Udiana:2004:3). Bagi partisipan modal, isu bagaimana pasar modal memproses informasi akuntansi, terutama laba dan komponennya merupakan hal yang penting.

Laba merupakan suatu pos dasar dan penting dalam laporan keuangan yang memiliki berbagai kegunaan dalam berbagai konteks. Pada umumnya laba merupakan ukuran keberhasilan kepengurusan manajemen atas pengelolaan sumber daya suatu perusahaan dalam menjalankan usaha perusahaan, sehingga dari banyak kepentingan tersebut, terutama untuk kepentingan dari sisi pihak manajemen maka manajemen laba dari penyajian laporan keuangan ada indikasi selalu dilakukan. Akrual memungkinkan manajer mengkomunikasikan informasi privat mereka, oleh karena itu perusahaan meningkatkan kemampuan laba untuk mencerminkan nilai ekonomis perusahaan.

Adanya praktik manajemen laba menjelang merger dan akuisisi cenderung bertujuan untuk meningkatkan harga sahamnya sebelum stock merger agar mengurangi biaya pembelian perusahaan target. Keputusan manajemen perusahaan yang memilih untuk melakukan manajemen laba dengan cara incomeincreasing accruals akan membawa konsekuensi terhadap kinerja perusahaan yang akan mengalami suatu kenaikan pada periode sesudahnya.

Banyak penelitian yang membahas tentang adanya manajemen laba dalam proses akuisisi. Penelitian Rahmad dan Bakar (2002) yang dikutip oleh Udiana Sari telah membuktikan adanya manajemen laba melalui discretionary accrual pada perusahaan pengakuisisi sebelum merger dan akuisisi di Malaysia pada tahun sebelum akuisisi. Penelitian yang dilakukan Metta (2008) menunjukkan bahwa tidak ada indikasi manajemen laba sebelum merger dan akuisisi yang dilakukan dengan income increasing accruals. Selanjutnya kinerja keuangan perusahaan yang diukur dengan rasio total assetturnover mengalami kenaikan sesudah merger dan akuisisi.
Gumanti (2000) mengatakan bahwa fenomena manajemen laba tidak selamanya terbukti, walaupun secara teoritis memungkinkan atau ada peluang bagi manajemen untuk mengelola laba yang dilaporkan. Gumanti menyelidiki apakah pemilik perusahaan yang akan go public memilih metode-metode akuntansi dengan melakukan income-in-creasing discretionary accrual pada periode sebelum penawaran perdana.

Penelitian tentang kinerja keuangan dilakukan Payamta (2001) periode akuisisi 1990-1996 de-ngan periode pengamatan empat tahun (dua tahun sebelum dan dua tahun sesudah akuisisi). Rasio Keuangan yang digunakan adalah Current $R a$ tio,Quick Ratio, DR,Network to debt ratio,Total asset turnover,ROI dan NPM. Hasil penelitiannya menunjukkan adanya peningkatan kinerja keuangan setelah perusahaan melakukan akuisisi.

Penelitian ini membahas mengenai fenomena manajemen laba khususnya pada perusahaan-perusahaan yang listing di pasar modal Indonesia (BEI) yang melakukan kegiatan akuisisi. Hal yang melatar belakangi penelitian ini adalah untuk mengetahui kebenaran perusahaan melakukan manaje-men laba sebe lum akuisisi serta untuk mengetahui bagaimana kinerja keuangan perusahaan pengakuisisi sebelum dan setelah melakukan akuisisi.

Penelitian ini dilakukan dengan tujuan untuk melihat konsistensi dari hasil penelitian-penelitian terdahulu yang pro dan kontra mengenai terjadi tindakan manajemen laba pada perusahaan pengakuisisi sebelum perusahaan tersebut melaksanakan kegiatan merger dan akuisisi. Melalui pengambi-lan sampel yang berbeda dari penelitian terdahulu, peneliti juga ingin melihat perbedaan kinerja ke-uangan perusahaan pengakuisisi pada saat sebelum dan sesudah akuisisi.

Berdasarkan hasil-hasil penelitian diatas diperoleh adanya perbedaan hasil penelitian (research gap) yang dilakukan oleh para peneliti. Research gap yang telah dipaparkan diatas dapat dijadikan permasalahan dalam penelitian ini. Hal ini akan mengkaji ulang penelitian sebelumnya dengan memperbarui periode penelitian dan menge-tahui pengaruh manajemen laba dan kinerja keuangan perusahaan pengakuisisi pada saat sebelum dan sesudah akuisisi. Dengan demikian penelitian ini diberi judul "Analisis Manajemen Laba dan Kinerja Keuangan Perusahaan Pengakuisisi Sebelum dan Setelah Akuisisi”. 


\section{TINJAUAN PUSTAKA}

Laporan keuangan utamanya dibuat berdasarkan basis akrual. Informasi mengenai laba perusahaan berdasarkan akuntansi akrual biasanya memberikan indikasi kemampuan perusahaan untuk menghasilkan arus kas saat ini dan masa depan yang lebih baik dibandingkan dengan informasi yang dibatasi oleh aspek keuangan berupa penerimaan dan pembayaran kas. Akuntansi akrual bertujuan untuk memberikan informasi kepada pemakai me-ngenai konsekuensi aktivitas usaha terhadap arus kas perusahaan di masa depan secepat mungkin dengan tingkat kepastian yang layak. Hal ini dapat dicapai dengan mengakui pendapatan dan beban saat terjadi,tanpa memperhatikan apakah terdapat arus kas pada saat yang bersamaan. Arti umum akrual adalah penyesuaian akuntansi yang meru-bah arus kas operasi menjadi laba bersih (Jordan, et al, 2004: 117).

Perbedaan antara akuntansi akrual dan akuntansi kas merupakan masalah tepat waktu maupun pengaitan yang selalu terdapat pada akuntansi kas (Jordan, et al, 2004:118). Akuntansi akrual meskipun mempengaruhi neraca dan laporan arus kas juga memiliki pengaruh yang khusus terhadap laporan laba rugi melalui; pertama, pengakuan pendapatan. Pendapatan diakui saat diperoleh dan saat direalisasi. Pendapatan terjadi ketika perusahaan menyerahkan produk atau jasanya. Pendapatan di-realisasi saat memperoleh kas dari penyerahan barang atau jasa.Kedua, pengaitan beban. Akun-tansi akrual mengharuskan pengaitan beban dengan pendapatan. Proses pengaitan ini berbeda untuk dua jenis beban, yaitu biaya produk dan jasa diakui saat produk atau jasa diserahkan dan biaya perio-de biasanya dikaitkan dengan pendapatan periode tertentu.

Laba akuntansi merupakan selisih antara pen-dapatan dan biaya. Ikatan Akuntan Indonesia me-miliki pengertian sendiri mengenai income. Akuntan mendefinisikan laba akuntansi yaitu perbedaan antara pendapatan yang direalisasi dari transaksi yang terjadi selama satu periode dengan biaya yang berkaitan dengan pendapatan tersebut. Penguku-ran terhadap laba merupakan penentuan jumlah ru-piah laba yang dicatat dan disajikan dalam laporan keuangan (Aida, 2006:139).
Pengukuran besarnya laba sangat tergantung pada besarnya pendapatan dan biaya, karena laba adalah bagian dari pendapatan maka konsep penghimpunan dan realisasi pendapatan juga berlaku untuk laba (Aida, 2006:140). Manajemen laba terjadi karena beberapa alasan seperti untuk meningkatkan kompensasi, menghindari persyaratan utang, memenuhi ramalan analis, dan memengaruhi harga saham. Dalam kondisi perusahaan akan men-jual sahamnya kepada publik, manajer perlu memberikan informasi kepada publik mengenai kondisi keuangan perusahaan. Hal ini mendorong manajer untuk melakukan earnings management.

Ada beberapa bentuk manajemen laba, diantaranya adalah taking a bath, income minimization, income maximization dan income smoothing. Taking a bath digunakan selama periode organizational stress atau reorganisasi, untuk mencapai prestasi dan posisi keuangan suatu pe-rusahaan, seorang analis keuangan memerlukan ukuran tertentu. Ukuran yang sering kali digunakan adalah rasio atau indeks yang menunjukkan hubu-ngan antara dua data keuangan (Scott dalam Metta: 2009: 37).

Beberapa alasan dilakukan manajemen laba antara lain pertama, manajemen laba dapat meningkatkan kepercayaan pemegang saham terhadap manajer. Manajemen laba berhubungan erat dengan tingkat perolehan laba atau prestasi usaha suatu organisasi, hal ini karena tingkat keuntungan atau laba dikaitkan dengan prestasi manajemen dan juga besar kecilnya bonus yang akan diterima oleh manajer.

Kedua, manajemen laba dapat memperbaiki hubungan dengan pihak kreditor.Perusahaan yang terancam default yaitu tidak dapat memenuhi kewajiban pembayaran utang pada waktunya, perusahaan berusaha menghindarinya dengan membuat kebijakan yang dapat meningkatkan pen-dapatan maupun laba. Ketiga, manajemen laba dapat menarik investor untuk menanamkan mo-dalnya terutama pada perusahaan go publik pada saat IPO.

Nanang (2005:51) mengemukakan bahwa analisis dapat dilakukan dengan membandingkan satu periode dengan periode sebelumnya, sehingga dapat diketahui adanya kecenderungan selama periode tertentu. Jika manajer merasa harus mela- 


$$
\text { | ! " \#\$ \% \& ! \# \&\%"'" }
$$

porkan kerugian dalam perusahaan, maka ia akan melaporkan dalam jumlah besar. Dengan tindakan ini manajer berharap dapat meningkatkan laba yang akan datang dan kesalahan atas kerugian perusa-haan dapat ditimpahkan ke manajer lama, jika ter-jadi pergantian manajer. Income minimization dipilih selama periode dengan profitabilitas tinggi, sehingga jika periode yang akan datang diperkirakan laba turun drastis, dapat diatasi dengan pengambilan jatah laba sebelumnya (Muhammad, 2006:36)

Income maximization dilakukan manajer terutama untuk tujuan mendapatkan bonus. Perusahaan yang berada pada pelanggaran syarat perjanjian utang juga melakukan income maximization, income smoothing dilakukan dengan meratakan laba yang dilaporkan, dengan tujuan pelaporan eksternal. Secara umum penelitian tentang manajemen laba menggunakan pengukuran berbasis akrual (accrual-based measure) dalam mendeteksi ada tidaknya manipulasi (Muhammad, 2006:37).

Menurut (Nanang, 2005:51) mengemukakan bahwa rasio dapat dibedakan yaitu perbandingan internal adalah membandingkan rasio pada saat ini dengan rasio pada masa lalu dan masa yang akan datang dalam perusahaan yang sama dan perbandingan eksternal, sumber-sumber rasio industri yaitu membandingkan rasio perusahaan dengan perusahaan-perusahaan sejenis dengan rata-rata industri pada saat yang sama. Secara garis besar ada 4 jenis rasio yang dapat digunakan untuk me-nilai kinerja keuangan perusahaan yaitu;

Pertama, rasio likuiditas yaitu rasio yang menunjukkan hubungan antara kas perusahaan dan aktiva lancar lainnya dengan hutang lancar. Rasio likuiditas digunakan untuk mengukur kemampuan perusahaan dalam memenuhi kewajiban-kewajiban finansialnya yang harus segera dipenuhi atau kewajiban jangka pendek.Kedua, rasio aktivitas atau rasio efisiensi yaitu rasio yang mengukur efisiensi perusahaan dalam menggunakan aset-asetnya.Ketiga, rasio leverage finansial yaitu rasio yang mengukur seberapa banyak perusahaan menggunakan dana dari hutang (pinjaman). Keempat, ra-sio keuntungan atau rentabilitas yaitu rasio yang menunjukkan kemampuan perusahaan untuk memperoleh keuntungan dari penggunaan modalnya.
Akuisisi adalah pembelian suatu perusahaan oleh perusahaan lain atau oleh kelompok investor. Akuisisi sering digunakan untuk menjaga ketersediaan pasokan bahan baku atau jaminan produk akan diserap oleh pasar.Akuisisi berkembang pada era tahun 1970-an. Proses ini didorong oleh faktorfaktor sebagai berikut (Jeff, 1997:14) semakin menyatunya sistem perekonomian regional dan perekonomiandunia, adanya ekspansi perusahaan-perusahaan MNC ke berbagai negara, berbagai terobosan teknologi informasi dan telekonumikasi setelah tahun 1980 yang memudahkan proses alih informasi dan kapital.

Setelah faktor-faktor tersebut maka muncul faktor lain yang dijadikan alasanperusahaan melakukan akuisisi yaitu (Abdul, 2003:10) mendapatkan cashflow dengan cepat karena produk dan pasar sudah jelas, memperoleh kemudahan dana atau pembiayaan karena kreditor lebih percaya dengan perusahaan yang telah berdiri dan mapan, memperoleh karyawan yang telah berpengalaman. Tahapan dalam proses akuisisi bisa jadi berbeda tergantung dari karakteristik atau kriteria akuisisi serta kompleksitas permasalahan yang akan diha-dapi. Proses akuisisi dapat disajikan dalam Gam-bar 1:

Pada tahapan paling awal ini perusahaan men-cari dan mengumpulkan informasi sebanyak mungkin perusahaan-perusahaan yang potensial untuk diakuisisi. Identifikasi ini tidak terlepas dari motivasi perusahaan dan akan menentukan perusahaan yang seperti apa yang akan dijadikan target akuisisi. Pada tahap identifikasi awal ini berbagai informasi dikumpulkan untuk melihat karakteristik perusahaan target.

Tahap selanjutnya adalah screening yaitu proses menyaring sekaligus memilih mana diantara calon target tersebut yang paling layak untuk diakuisisi. Proses screening ini tidak dilakukan apabila perusahaan hanya mengidentifikasi satu calon perusahaan target. Tahap selanjutnya yaitu penawaran formal yaitu perusahaan membentuk tim yang bertanggung jawab dalam pelaksanaan merger dan akuisisi. Apabila perusahaan merekrut personal ahli dari pihak luar,maka pihak ini akan bergabung dalam tim dan selanjutnya tim melakukan pendekatan dengan target. Tahap yang 


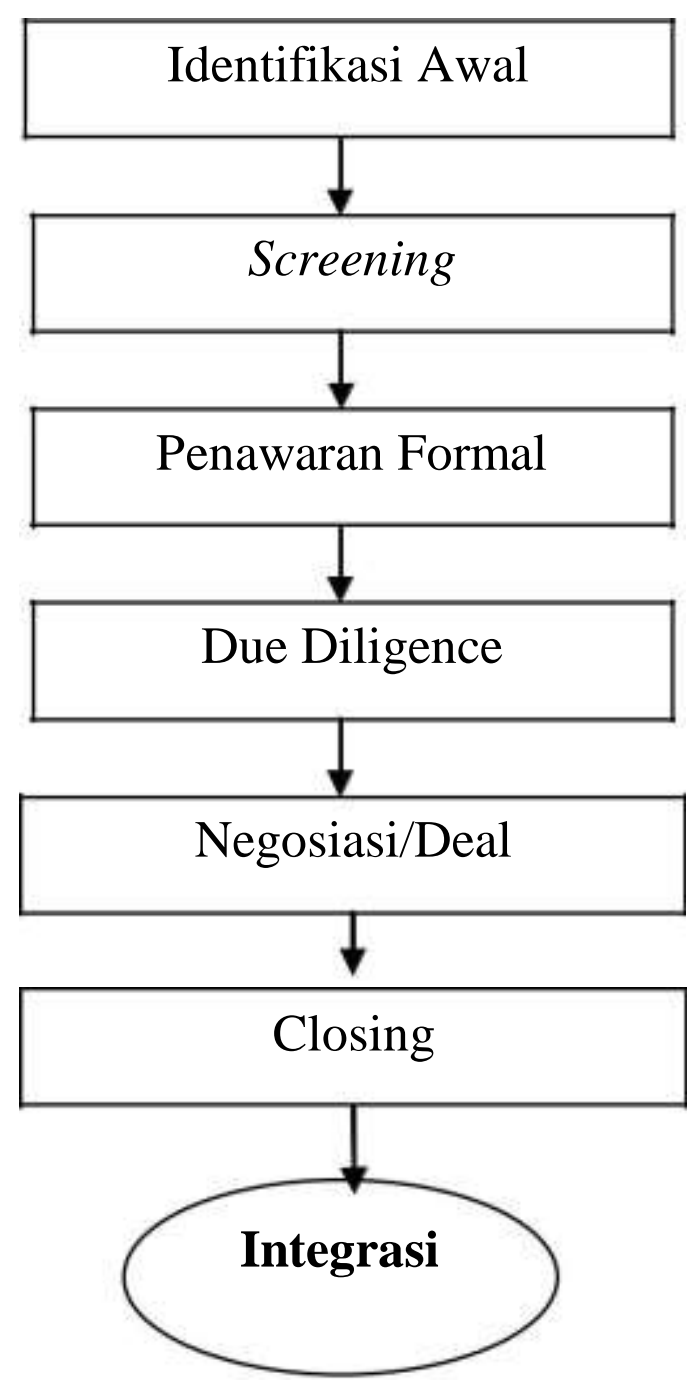

Gambar 1. Proses Pentahapan Akuisisi

keempat yaitu Due Diligence yaitu investigasi yang menyeluruh dan mendalam terhadap berbagai as-pek perusahaan target.

Tahap yang kelima adalah negosiasi/deal, pada tahap ini terdapat dua pihak pada perusahaan target yang harus memberikan persetujuan agar proses akuisisi berjalan normal yaitu manajemen dan pemegang saham. Jika kedua pihak ini setuju dengan syaratsyarat yang disepakati antara pe-ngakuisisi dengan target,maka deal akan terlak-sana.
Tahap terakhir adalah integrasi yaitu tahap di-mulainya kehidupan baru setelah perusahaan me-lakukan penggabungan bisnis sebagai satu kesa-tuan entitas ekonomi. Perusahaan hasil merger atau pengakuisisi mulai melaksanakan perencanaan stra-tegik yang telah disusun sebelumnya (Abdul, 2003:118).

Suatu penelitian di Amerika menunjukkan bahwa sebagian besar akuisisi tidak berjalan atau mengalami kegagalan. Alasan utama kegagalan tersebut adalah menyusun strategi akuisisi. Disamping 
terdapat kesuksesan akuisisi seperti pada General Electric terhadap RCA,akuisisi Unilever terhadap Pond's juga terdapat kegagalan pada akuisisi Pan Am terhadap Republik Steel (Bussines Week da-lam Marcel, 1992:29). Penyebab dari kegagalan tersebut meliputi; pengalaman pengelolaan akuisisi, kegagalan mempertahankan dan memberi motivasi kepada pimpinan dan karyawan perusahaan tar-get, pembelian perusahaan target yang relatif besar sehingga mengalami kesulitan dalam hal penyediaan berbagai sumber daya, kecurangan yang terjadi pada perusahaan target, dan kegagalan meramal-kan peristiwa-peristiwa yang akan terjadi

Pertama, manajer dapat menentukan kapan waktu akan melakukan manajemen laba melalui kebijakannya. Hal ini biasanya dikaitkan dengan segala aktivitas yang dapat mempengaruhi aliran kas dan juga keuntungan yang secara pribadi merupakan wewenang dari para manajer. Kedua, keputusan manajer untuk menerapkan suatu kebijakan akuntansi yang wajib diterapkan oleh suatu perusahaan yaitu antara menerapkan lebih awal atau menunda sampai saat berlakunya kebijakan tersebut. Ketiga, upaya manajer untuk mengganti atau merubah suatu metode akuntansi tertentu dari sekian banyak metode yang dapat dipilih yang tersedia dan diakui oleh badan akuntansi yang ada (GAAP)

Hal tersebut dilakukan oleh manajer dengan tujuan untuk menarik perusahaan sasaran agar mau diambil alih karena menunjukkan kinerja keuangan yang baik. Akuisisi diharapkan menciptakan nilai tambah yang memiliki tolok ukur yang jelas. Nilai tambah diukur secara kuantitatif sehingga dapat di-perbandingkan dengan kondisi sebelum akuisisi. Nilai tambah dapat dicari dengan menggunakan rumus:

Nilai tambah $=$ Nilai agregat setelah akuisisi - nilai agregat sebelum akuisisi.

Atau $=\mathrm{Vab}=(\mathrm{Va}+\mathrm{Vb})($ Abdul:2003:51 $)$

Keterangan:

$\mathrm{Vab}=$ Nilai perusahaan setelah akuisisi

$\mathrm{Va}=$ Nilai perusahaan A sebelum akuisisi

$\mathrm{Vb}=$ Nilai perusahaan $\mathrm{B}$ sebelum akuisisi

Masing-masing elemen perusahaan memandang dari sisi peningkatan kapabilitas manajerial dan skill mereka. Pemegang saham mendefinisikan- nya dari adanya peningkatan terhadap laba per lembar saham. Para pekerja mendefinisikan nilai tambah melalui peningkatan kesejahteraan dan produktivitas.Walaupun masing-masing mendefinisikannya secara berbeda namun pada prinsipnya ada satu hal yang ingin tercipta yaitu tercapainya suatu kondisi yang lebih baik setelah akuisisi.

Penelitian Rahmad dan Bakar (2002) yang melakukan penelitian pada tahun 1999-2001, ob-yek penelitian adalah merger dan akuisisi di Malay-sia dan hasil penelitiannya membuktikan adanya manajemen laba melalui discretionary accrual pada perusahaan pengakuisisi sebelum merger dan akuisisi.

Penelitian yang dilakukan Anisa Metta (2009), periode penelitian 2008-2009 obyek pe-nelitian perusahaan di Bursa Efek Jakarta yang me-lakukan merger dan hasil penelitiannya menunjuk-kan bahwa tidak ada indikasi manajemen laba se-belum merger dan akuisisi yang dilakukan dengan income increasing accruals. Selanjutnya kinerja keuangan perusahaan yang diukur dengan rasio total assetturnover mengalami kenaikan sesudah merger dan akuisisi.

Penelitian perusahaan manufaktur juga dilakukan Payamta periode akuisisi 1990-1996 dengan periode pengamatan empat tahun (dua ta-hun sebelum dan dua tahun sesudah akuisisi). Rasio keuangan yang digunakan adalah Current Ratio, Quick Ratio, DR, Network to debt ratio,Total as-set turnover,ROI dan NPM. Hasil penelitiannya menunjukkan kinerja keuangan perusahaan meningkat setelah perusahaan melakukan akuisisi.

Penelitian Igan Budiasih (2008) dengan tahun penelitian 2002-2006, fokus penelitian tentang faktor-faktor yang mempengaruhi manajemen laba dengan objek perusahaan yang terdaftar di Bursa Efek Indonesia diperoleh hasilnya bahwa ukuran perusahaan, profitabilitas, dan dividendpayout ra-tio berpengaruh positif terhadap praktikperataan laba. Sementara itu, financial leverage tidak ber-pengaruh terhadap praktik perataan laba.

\section{METODE PENELITIAN}

Penelitian ini merupakan jenis penelitian komparatif yaitu penelitian yang bersifat membandingkan. Variabelnya adalah sama dengan penelitian variabel mandiri tetapi untuk sampel yang lebih dari 
satu atau dalam waktu yang berbeda (Sugiyono: 2002:11).

Manajemen laba dalam penelitian ini diukur dengan proxy discretionary accruals (DA) yang menggunakan model Modified Jones (Jones Modifikasian). Model perhitungan manajemen laba adalah sebagai berikut:

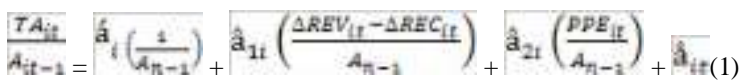

(Hadri dan Udiana: 2003:25)

Total akrual untuk periode $\mathrm{t}$ dinyatakan dalam per-samaan: $\mathrm{TA}_{\mathrm{it}}=\mathrm{NI}_{\mathrm{it}}-\mathrm{OCF}_{\mathrm{it}}(2)$

(Hadri dan Udiana: 2003:26)

Keterangan:

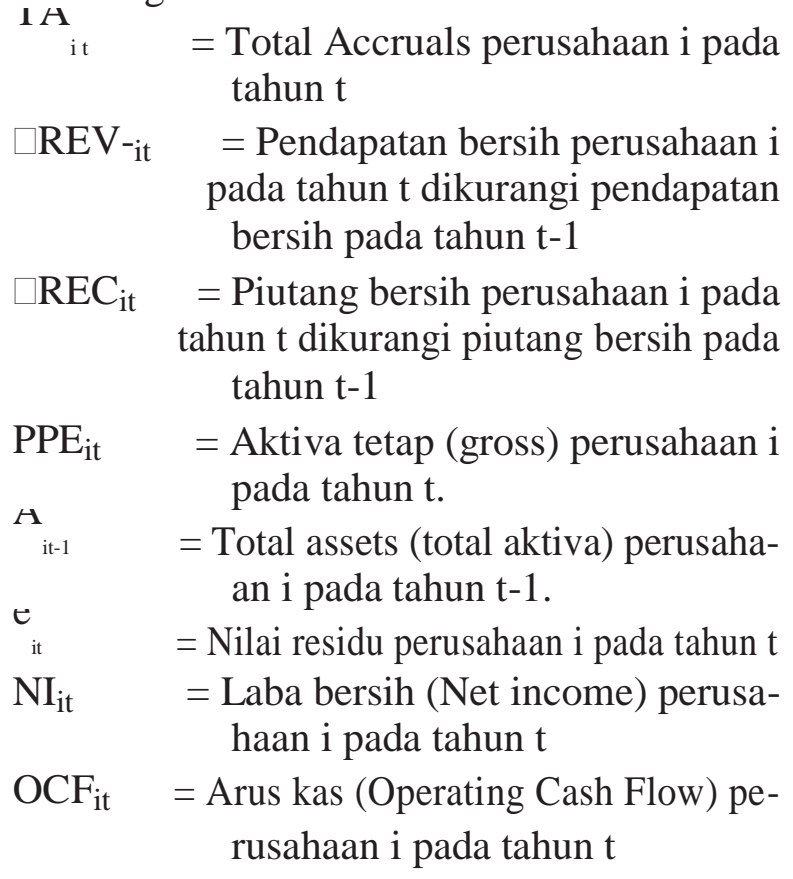

Non DiscretionaryAccruals (NDA) dapat diten-tukan dengan persamaan: (Hadri dan Udiana: 2003: 28)

$$
\mathrm{NDA}_{\mathrm{it}}=\hat{a}_{1}\left(\frac{2}{A_{n-1}}\right)+\hat{a}_{14}\left(\frac{\Delta R E V_{i t}-\triangle R E C_{i t}}{A_{n-1}}\right)+\hat{a}_{2 i}\left(\frac{P P E_{E}}{A_{n-1}}\right)+\hat{a}_{i t}(3)
$$

Setelah melakukan regresi model di atas, DA yang dilakukan oleh setiap perusahaan dapat dihi-tung dengan persamaan sebagai berikut:

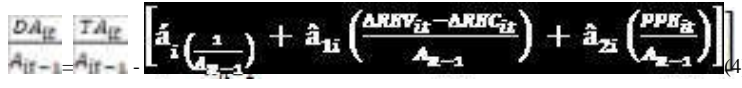

(Hadri dan Udiana:2003:28)

Atau

$\mathrm{DA}_{\mathrm{it}}=\mathrm{TA}_{\mathrm{it}}-\mathrm{NDA}_{\mathrm{it}}(5)$

Keterangan:

NDA $_{\text {it }}=$ Non Discretionary Accruals perusahaan i pada tahun $t$

$\mathrm{Da}_{\mathrm{it}}=$ DiscretionaryAccruals perusahaan i pada tahun $\mathrm{t}$

Kinerja keuangan didefinisikan sebagai prestasi manajemen dalam hal ini manajemen keuangan dalam mencapai tujuan perusahaan yaitu menghasilkan keuntungan dan meningkatkan nilai perusahaan.Kinerja keuangan diukur dengan menggunakan rasio aktivitas, profitabilitas, dan solvabilitas.

(1) RasioAktivitas

TotalAssetTurnover $($ TATO $)=$ Penjualan/ To-talAktiva (6)

(2) Rasio Profitabilitas

Return on investment $(\mathrm{ROI})=\frac{\text { Net Profit }}{\tau_{n+n !} \text { Asset }}(7)$

Net Profit Margin $(\mathrm{NPM})=$ EAT $/$ Nett Sales $(8)$

(Yopie: 2002:71)

Penelitian ini menggunakan data sekunder. Jenis data yang digunakan dalam penelitian adalah data yang diperoleh dari Bursa Efek Indonesia dan dari sumber yang lain, seperti ICMD dan dari jurnal-jurnal penelitian. Penelitian ini dilakukan di PT. Bursa Efek Indonesia (BEI) dengan mengakses langsung ke situs yang berhubungan dengan Bursa Efek Indonesia, yaitu www.bapepam.go.id, www.idx.co.id dan www.ebursa.com

Populasi dalam penelitian ini adalah perusahaan yang melakukan akuisisi mulai tahun 2006 sampai dengan tahun 2008, kecuali perusahaan yang bergerak dalam bidang keuangan. Teknik pengambilan sampel dilakukan secara: non probability sampling, yaitu dengan pendekatan purposive sampling yaitu teknik sampling dengan menggunakan pertimbangan dan batasan tertentu sehingga sampel yang dipilih relevan dengan penelitian. Kriteria sampel adalah sebagai berikut. 
Perusahaan publik yang terdaftar di Bursa Efek Indonesia dan melakukan akuisisi antara tahun 2006 sampai dengan tahun 2008. Perusahaan termasuk industri manufaktur dan industri lain selain kelompok perusahaan yang bergerak di bidang asuransi dan industri finance atau perusahaan perbankan dan lembaga keuangan lainnya. Perusahaan memiliki tanggal akuisisi yang jelas. Menerbitkan laporan keuangan auditan secara lengkap selama dua tahun berturut-turut sebelum akuisisi serta dua tahun setelah akuisisi dengan periode berakhir per 31 Desember. Menggunakan mata uang Indonesia (rupiah) dalam laporan keuangannya.

Langkah-langkah dalam analisis data ini adalah mencari nilai total accrual yang akan dijadikan dasar dalam mencari nilai discretionary accrual dan non discretionary accrual. Berdasarkan rumus yang ada maka akan diperoleh nilai discretionary accrual dan non discretionary accrual perusahaan baik sebelum perusahaan melakukan akuisisi maupun perusahaan setelah melakukan akuisisi. Nilai discretionary accrual dan non discretionary accrual akan dibandingkan diantara kedua parameter tersebut akan diketahui nilai mana yang dominan terhadap masing-masing perusa-haan. Langkah selanjutnya setelah nilai discretion-ary accrual dan non discretionary accrual di-ketahui maka akan diperoleh satu kesimpulan apa-kah perusahaan melakukan manajemen laba atau tidak.

Peneliti mencari nilai rasio keuangan yang sudah ditetapkan sebagai variabel yaitu profitabilitas dan aktivitas sebelum akuisisi dan setelah akuisisi, tujuannya untuk memperoleh hasil kinerja keuangan perusahaan pengakuisisi apakah mengalami pening-katan,penurunan dalam kondisi keuangan yang se-hat atau tidak. Dari hasil tersebut maka akan di-peroleh suatu kesimpulan mengenai kinerja ke-uangan perusahaan pengakuisisi sebelum dan se-sudah melakukan akuisisi.

\section{HASIL PENELITIAN DAN PEMBAHASAN}

Populasi dalam penelitian ini adalah perusahaan yang melakukan akuisisi periode tahun 20062008. Adapun daftar keseluruhan perusahaan yang melakukan merger dan akuisisi di Bursa Efek Indonesia periode 2006-2008 dapat dilihat pada tabel

1. Kriteria sampel dalam penelitian ini adalah se-bagai berikut: Perusahaan publik yang terdaftar di Bursa Efek Indonesia danmelakukan akuisisi antara tahun 2006 sampai dengan tahun 2008.Perusahaan termasuk industri manufaktur dan industri lain selain kelompok perusahaan yang bergerak di bidang asu-ransi dan industri finance atau perusahaan perban-kan dan lembaga keuangan lainnya. Perusahaan memiliki tanggal akuisisi yang jelas.Menerbitkan la-poran keuangan auditan secara lengkap selama dua tahun berturut-turut sebelum akuisisi serta dua tahun setelah akuisisi dengan periode berakhir per 31 Desember. Menggunakan mata uang Indonesia (Rupiah) dalam laporan keuangannya.

Berdasarkan data pada Tabel 1 dan berdasarkan kriteria sampel yang diajukan dalam penelitian ini, maka peneliti menetapkan perusahaan yang memenuhi syarat untuk dijadikan sampel dalam penelitian ini adalah sebagai berikut, PTAdes Water Indonesia Tbk, PT Mobile 8 Telecom (FREN), PT Selamat Sempurna (SMSM), dan PT Bumi Resourches Tbk, sedangkan perusahaan yang lain tergolong perusahaan yang melakukan merger dan merupakan perusahaan keuangan se-hingga tidak memenuhi persyaratan sebagai sampel.

PT. AdesWaters Indonesia Tbk, awalnya didirikan dengan nama PTAlfindo Putrasetia di tahun 1985, nama perseroan telah diubah beberapa kali terakhir di tahun 2004. Berdasarkan Anggaran Dasar Perusahaan, ruang lingkup kegiatan perusahaan adalah pengolahan dan distribusi air minum dalam kemasan.Untuk menghindari kesamaan nama dengan produk perusahaan, PT Ades Waters Indonesia (ADES) berubah nama menjadi PT Akasha Wira InternationalTbk. Pergantian nama dilakukan untuk menghindari keidentikan dengan produk yang dihasilkannya karena perusahaan mempunyai multi-produk, bukan hanya air mineral Ades. Pada tahun 2008 ADES mencatatkan rugi bersih sebesar Rp 15,2 miliar, sementara pada tahun 2007 rugi bersih tercatat $\mathrm{Rp}$ 154,85 miliar. Sedangkan penjualan yang dicatatkan perseroan pada tahun 2008 se-besar Rp 129,54miliar. Pada tahun 2006 PT. Pamargha Indojatim diakusisi oleh PT. Ades Water Indonesia,Tbk 
Tabel 1 Daftar Perusahaan MergerAkuisisi 2006 - 2008

\begin{tabular}{|c|c|c|c|c|c|}
\hline \multirow[t]{2}{*}{ No } & \multicolumn{3}{|c|}{ Waktu } & \multirow[b]{2}{*}{ Keterangan } & \multirow{2}{*}{ Jenis } \\
\hline & Tahun & Bulan & Tanggal & & \\
\hline 1 & 2006 & Juli & 30 & PT Pamaroha Indoiatim ke dalam PT Ades Water & Akuisisi \\
\hline 2 & 2006 & Okt & 13 & $\begin{array}{l}\text { Indonesia } \\
\text { PT. Andhi Candhra Automotive Products ke dalam PT. } \\
\text { Selamat Sempurna }\end{array}$ & Akuisisi \\
\hline 3 & 2006 & Juli & 20 & PT. Metamedia Technologi \& PT. Nusantara Konstruksi & Merger \\
\hline 4 & 2006 & Sept & 11 & $\begin{array}{l}\text { Indonesia } \\
\text { PT. Surya Toto Indonesia \& PT. Surya Pertiwi Paramita }\end{array}$ & Merger \\
\hline 5 & 2006 & Juni & 15 & $\begin{array}{l}\text { PT. Energi Mega Persada ke dalam PT. Bumi } \\
\text { Resourches }\end{array}$ & Akuisisi \\
\hline 6 & 2007 & Maret & 22 & $\begin{array}{l}\text { PT. Komunikasi Seluler Indonesia, PT. Metro Seluler } \\
\text { Indonesia }\end{array}$ & Akuisisi \\
\hline & & & & $\begin{array}{l}\text { PT. Telekomindo Seluler Raya ke dalam PT. Mobile- } 8 \\
\text { Telecom }\end{array}$ & \\
\hline 7 & 2008 & Juni & 3 & PT. Bank Lippo \& PT. Bank Niaga & Merger \\
\hline 8 & 2008 & Feb & 6 & PT. Bank Multicor ke dalam PT. Bank Windu Kertajana & Akuisisi \\
\hline
\end{tabular}

PT. Mobile -8 Telecom adalah perusahaan operator seluler berbasis CDMA yang didirikan pada bulan Desember 2002. Mobile-8 memiliki produk layanan dengan nama pasar nama FREN, yang diluncurkan pada tanggal 8 Desember 2003. Saat ini layanan FREN masih mencakup pulau Jawa, namun tidak menutup kemungkinan akan ada ekspansi ke seluruh wilayah Indonesia. Pada tahun 2007 PT. Komunikasi Seluler Indonesia, PT.Metro Seluler Indonesia, PT.Telekomindo Seluler Raya diakuisisi oleh PT.Mobile-8 Telecom.

PT. Bumi Resourches merupakan jenis perusahaan pertambangan dan minyak. Perusahaan melakukan penawaran IPO pada tahun 1990 dan mendaftarkan sahamnya secara keseluruhan pada Bursa Efek Jakarta dan Bursa Efek Surabaya. Pada tahun 2001 perusahaan mengakuisisi empat perusahaan minyak di Kalimantan diantaranya di daerah Senakin, Satui, Asam- Asam dan Batulicin. Pada tahun 2004 perusahaan memperoleh sebagian saham dari PT. Ekakarsa Yasakarya Indonesia dengan jumlah 19,9\% saham dan hasilnya perusahaan menjadi pemilik keseluruhan perusahaan dengan tingkat kepemilikan saham 99.9\%. Pada tahun
2006 perusahaan kembali mengakuisisi PT. Energi Mega Persada.

PT Selamat Sempurna Tbk didirikan di Indo-nesia pada tanggal 19 Januari 1976 berdasarkan akta Notaris Ridwan Suselo, S.H. No. 207. Akta pendirian tersebut telah disahkan oleh Menteri Ke-hakiman dalam Surat Keputusan No. Y.A.5/96/5 tanggal 22 Maret 1976. Anggaran Dasar Perusa-haan telah mengalami beberapa kali perubahan, ter-akhir dengan akta Notaris tanggal 6 Juli 2001 se-hubungan dengan pemecahan nilai nominal saham perusahaan (stock split). Sesuai anggaran dasar Perusahaan, ruang lingkup kegiatan Perusahaan terutama adalah bergerak dalam bidang industri alat-alat perlengkapan (suku cadang) dari berbagai macam alat- alat mesin pabrik dan kendaraan, dan yang sejenisnya.

Data yang diperlukan dalam penelitian ini adalah data laporan keuangan tahunan perusahaan pengakuisisi dan data keuangan dua tahun pasca perusahaan melakukan akuisisi. Laporan keuangan yang diperlukan dalam penelitian ini adalah neraca untuk melihat nilai aktiva dan kewajiban perusahaan, laporan laba rugi untuk melihat nilai penjualan 
bersih perusahaan dan laporan arus kas perusahaan untuk melihat nilai arus kas bersih perusahaan yang akan dijadikan dasar untuk menilai manajemen laba perusahaan. Laporan keuangan dalam penelitian ini dapat dilihat dalam lampiran.

Berdasarkan kondisi umum data yang akan dianalisis maka, langkah-langkah dalam analisis data ini adalah mencari nilai total accrual yang akan dijadikan dasar dalam mencari nilai discretionary accrual dan non discretionary accrual. Berdasarkan rumus yang ada maka akan diperoleh nilai DA dan NDA perusahaan baik sebelum perusa-haan melakukan akuisisi maupun perusahaan se-telah melakukan akuisisi. Nilai discretionary ac-crual dan non discretionary accrual akan diban-dingkan diantara kedua parameter tersebut akan diketahui nilai mana yang dominan terhadap ma-sing-masing perusahaan.

Langkah selanjutnya setelah nilai discretionary accrual dan nondiscretionary accrual dike-tahui maka akan diperoleh satu kesimpulan apakah perusahaan melakukan manajemen laba atau tidak, selanjutnya peneliti mencari nilai rasio keuangan yang sudah ditetapkan sebagai variabel yaitu profitabilitas, likuiditas dan aktivitas sebelum akuisisi dan setelah akuisisi, tujuannya untuk memperoleh hasil kinerja keuangan perusahaan pengakuisisi apakah mengalami peningkatan,penurunan dalam kondisi keuangan yang sehat atau tidak. Dari hasil tersebut maka akan diperoleh suatu kesimpulan mengenai kinerja keuangan perusahaan pengakuisisi sebelum dan sesudah melakukan akuisisi.

Model perhitungan manajemen laba adalah sebagai berikut:

$$
\frac{T A_{i t}}{A_{i t-1}}=\hat{a}_{i}\left(\frac{1}{A_{n-1}}\right)+\longdiv { \hat { a } _ { 1 i } ( \frac { \triangle R E V _ { i t } - \triangle R E C _ { i t } } { A _ { n - 1 } } ) } + \overline { \hat { a } _ { 2 i } ( \frac { P P E _ { i t } } { A _ { n - 1 } } ) } + \hat { a } _ { i t }
$$

Untuk penghitungan diskresionary accrual (DA) yaitu:

Tabel 2. Hasil Manajemen Laba Perusahaan

\begin{tabular}{|c|c|c|c|c|c|c|c|}
\hline \multirow{2}{*}{ Perusahaan } & \multirow{2}{*}{ Variabel } & \multicolumn{6}{|c|}{ Tahun } \\
\hline & & 2004 & 2005 & 2006 & 2007 & 2008 & 2009 \\
\hline \multirow[t]{2}{*}{ SMSM } & $\mathrm{DA}$ & 8,31 & 3,29 & Akuisisi & 13,82 & 1,22 & - \\
\hline & NDA & 9,87 & $-3,37$ & & $-16,38$ & $-1,61$ & - \\
\hline \multirow[t]{2}{*}{ ADES } & DA & $-84,83$ & 27,84 & Akuisisi & $-110,6$ & 20,52 & - \\
\hline & NDA & 47,07 & $-29,7$ & & 31,97 & $-12,78$ & \\
\hline \multirow[t]{2}{*}{ FREN } & DA & - & - & Akuisisi & $-5,92$ & $-0,63$ & 6,13 \\
\hline & NDA & - & - & & $-5,43$ & 0,52 & $-5,78$ \\
\hline \multirow[t]{2}{*}{ BUMI } & DA & 153,32 & 46,14 & Akuisisi & 216,36 & 143,63 & - \\
\hline & NDA & $-32,14$ & $-17,87$ & & $-107,27$ & $-3,08$ & - \\
\hline
\end{tabular}

Tabel 2 diatas menunjukkan hasil manajemen laba perusahaan pengakuisisi, sebelum perusahaan melakukan akuisisi dan setelah perusahaan melakukan akuisisi. Dapat diketahui bahwa penghitu-ngan manajemen laba perusahaan pengakuisisi an-tara discretionary accrual dengan non discretion-ary accrual berbeda dan cenderung lebih tinggi nilainya discretionary accrual. Hal ini membukti-kan bahwa ternyata perusahaan lebih memilih meng-gunakan discretionary accrual dalam labanya, ka- rena adanya peluang campur tangan manajemen dalam penentuan labanya.

PT. Selamat Sempurna memiliki nilai discretionary accrual antara tahun sebelum akuisisi dan tahun sesudah akuisisi mengalami peningkatan, sedangkan nilai non discretionary accrulanya bernilai negatif sampai setelah perusahaan melakukan akuisisi. PT.Ades Water Indonesia memiliki nilai discretionary accrual yang lebih kecil dan ke arah negatif. PT Mobile - 8 Telecom memiliki nilai dis- 
cretionary accrual yang lebih besar setelah perusahaan melakukan akuisisi namun lebih ke arah negatif. PT. Bumi Resourches memiliki nilai discretio-nary accrual sebelum dan setelah akuisisi adalah berbeda. Nilai setelah akuisisi lebih besar.

Ketika perusahaan sebelum melakukan akui-sisi nilai penghitungannya lebih besar dan pada pe-riode setelah akuisisi nilainya lebih kecil, hal ini menunjukkan bahwa tidak selamanya perusahaan melakukan manajemen laba sebelum perusahaan me- lakukan akuisisi, meskipun ada peluang untuk manajemen karena dari empat perusahaan tersebut dua diantaranya melakukan manajemen laba.

Berdasarkan hasil perhitungan keseluruhan rasio keuangan sebelum dan setelah perusahaan melakukan akuisisi maka diperoleh nilai perbandi-ngan kinerja keuangan antara sebelum akusisi dan setelah perusahaan melakukan akuisisi. Perbandi-ngan hasil tersebut dapat dilihat pada Tabel 3 dibawah ini:

Tabel 3. Net Profit Margin Perusahaan akuisisi

\begin{tabular}{|c|c|c|c|c|c|c|c|c|}
\hline No & Perusahaan & Rasio & 2004 & 2005 & 2006 & 2007 & 2008 & 2009 \\
\hline \multirow{3}{*}{1} & \multirow{3}{*}{ SMSM } & NPM & 0.07 & 0.07 & Akuisisi & $-0,007$ & 0.06 & \\
\hline & & ROA & $8 \%$ & $9 \%$ & & $-0,9 \%$ & $9 \%$ & \\
\hline & & TATO & 1.12 & 1.29 & & 1.28 & 1.45 & \\
\hline \multirow{3}{*}{2} & \multirow{3}{*}{ ADES } & NPM & $-1,18$ & $-0,82$ & Akuisisi & $-1,17$ & $-0,11$ & \\
\hline & & ROA & $-144 \%$ & $-56 \%$ & & $-86 \%$ & $-8 \%$ & \\
\hline & & TATO & 1.22 & 0.68 & & 0.73 & 0.70 & \\
\hline \multirow{3}{*}{3} & \multirow{3}{*}{ FREN } & NPM & & 0.05 & Akuisisi & 0.05 & $-1,3$ & $-1,96$ \\
\hline & & ROA & & $1 \%$ & & $1 \%$ & $-22 \%$ & $-15 \%$ \\
\hline & & TATO & & 0.19 & & 0.21 & 0.17 & 0.07 \\
\hline \multirow{3}{*}{4} & \multirow{3}{*}{ BUMI } & NPM & 0.12 & 0,07 & Akuisisi & 0.34 & 0.19 & \\
\hline & & ROA & $8 \%$ & $7 \%$ & & $27 \%$ & $12 \%$ & \\
\hline & & TATO & 0.71 & 1,01 & & 0.80 & 0.63 & \\
\hline
\end{tabular}

Berdasarkan data pada tabel 3 diatas maka dapat diperoleh hasil bahwa PT. Selamat Sempurna memiliki nilai Net Profit Margin sebelum akuisisi nilainya tetap,sedangkan setelah akuisisi nilainya menjadi menurun.

Rasio ini digunakan untuk melihat seberapa besar laba setelah pajak yang diperoleh perusahaan untuk tingkat penjualan tertentu. Return on Asset dari SMSM mengalami peningkatan antara sebelum perusahaan melakukan akuisisi dengan perusahaan setelah melakukan akuisisi dengan peningkatan sebesar $1 \%$.Rasio ini menunjukkan seberapa besar laba setelah pajak yang diperoleh nilainya mengalami penurunan bahkan ke arah negatif. ROA dari FREN juga pada posisi yang stabil yaitu nilainya tetap pada periode sebelum akuisisi, sedang-kan periode setelah akuisisi mengalami penurunan bahkan ke arah negatif. TATO dari FREN dari tahun sebelum akuisisi dan tahun sesudah akuisisi menga-lami penurunan.
PT. Bumi Resourches Tbk memiliki NPM peningkatan antara tahun sebelum akuisisi dan se-sudah akuisisi, meskipun peningkatannya tidak ter-lalu besar tetapi posisi BUMI stabil. Rasio ROA dari BUMI memiliki nilai yang stabil antara satu tahun sebelum akuisisi dengan dua tahun sebelum akuisisi, bahkan sampai setelah akuisisi kondisi rasio ini mengalami peningkatan. TATO dari BUMI pada tahun sebelum akuisisi mengalami peningkatan.

Akrual secara teknis merupakan perbedaan antara kas dan laba. Akrual merupakan komponen utama pembentuk laba dan akrual disusun berdasarkan estimasi- estimasi tertentu, misalnya biaya depresiasi untuk mengetahui besarnya biaya ini perlu diketahui umur (manfaat), dan metode depresiasi yang digunakan. Teori yang dikembangkan oleh Jones digunakan dalam penelitian ini sebagai dasar penelitian. Jones mengembangkan model pengestimasi akrual diskresioner untuk mendeteksi manajemen laba. Akrual diskresioner diperoleh dengan 
membandingkan akrual tahun $\mathrm{t}$, saat terjadinya manipulasi laba dengan rata- rata akrual perusahaan itu sendiri pada tahun-tahun sebelumnya.

Berdasarkan Perbandingan nilai akrual dalam perusahaan pengakuisisi maka diperoleh suatu hasil yang dapat dijadikan dasar bagaimana perusahaan pengakuisisi melakukan manajemen laba menjelang perusahaan melakukan akuisisi. Perbandingan nilai antara discretionary accrual dan non discretionary accrual dari tahun sebelum akuisisi dengan tahun sesudah akuisisi dapat digunakan sebagai dasar untuk melihat nilai total akrual yang menurut teori Jones itu bisa dimanipulasi.

Perbedaan nilai antara discretionary accrual dan non discretionary acrrual disebabkan nilai total akrual perusahaan pengakuisisi berbeda. Jika nilai total akrual negatif itu artinya perusahaan pengakuisisi tidak melakukan manajemen laba, ka-rena nilai total akrual negatif itu disebabkan oleh nilai net income yang rendah dibandingakan dengan nilai operational cash flow perusahaan. Nilai dis-cretionary accrual yang lebih tinggi antara sebelum akusisi dengan setelah akuisisi itu membuktikan bahwa perusahaan melakukan manajemen laba dengan mempengaruhi jumlah depresiasi atau pen-dapatan.

Perubahan pendapatan mempengaruhi perubahan akrual yang berasal dari modal kerja seperti piutang dan utang. Perubahan pendapatan digunakan sebagai variabel kontrol karena relatif objektif sebagai ukuran operasi perusahaan sebelum manipulasi oleh manajer. Namun,tidak sepenuhnya perubahan pendapatan adalah objektif, karena te-tap bisa melakukan manajemen laba melalui manipulasi pendapatan seperti percepatan pengiriman barang agar perusahaan dapat mengakui pendapatan lebih awal.

Berdasarkan perhitungan diatas perusahaan pengakuisisi yang memiliki nilai diskresional akrual negatif adalah ADES pada periode sebelum akui-sisi dan hasilnya juga tetap negatif pada periode setelah akusisi. Hal ini dapat diartikan bahwa ADES cenderung tidak melakukan manajemen laba sebelum perusahaan melakukan akuisisi. SMSM dan BUMI memiliki nilai diskresional akrual sebelum akuisisi lebih tinggi dibanding setelah akui-sisi. FREN memiliki nilai diskresional akrual sebe-lum akuisisi lebih kecil dibandingkan setelah akui- sisi. Hasil tersebut dapat diartikan bahwa dari ke-seluruhan perusahaan pengakuisisi tidak semuanya terbukti melakukan manajemen laba dengan cara income increasing accrual meskipun ada peluang dari pihak manajemen untuk melakukan manipulasi laba.

Kinerja keuangan perusahaan pengakuisisi berada dalam kondisi yang sehat jika dilihat dari segi rasio keuangan. Ada satu perusahaan yang rasio keuangannya berada pada kondisi tidak sehat yaitu FREN yang nilainya jauh berbeda dengan rasio sebelum akuisisi. Kinerja keuangan perusahaan sebelum akuisisi dan setelah akuisisi cenderung berbeda. Perbedaan tersebut lebih ke arah penurunan kinerja keuangan, yang cenderung ke arah negatif dari posisi perusahaan sebelum melakukan akuisisi.

Hasil penelitian ini tidak konsisten dengan beberapa hasil penelitian sebelumnya, seperti hasil penelitian yang dilakukan oleh Rahman dan Bakar (2002) yang menunjukkan bahwa perusahaan pengakuisisi cenderung melakukan praktik manajemen laba dengan discretionary accrual pada periode sebelum atau menjelang pelaksanaan akuisisi.

Penelitian Wirawan Gerianta (2002) juga membuktikan bahwa perusahaan melakukan manajemen laba sebelum melakukan akuisisi. Ada satu hasil penelitian yang konsisten dengan peneli-tian ini yaitu Metta (2008) yang menyebutkan bah-wa tidak selamanya perusahaan melakukan ma-najemen laba sebelum perusahaan melakukan akuisisi dengan income increasing acrrual.

\section{SIMPULAN}

Penelitian ini tidak membuktikan bahwa perusahaan pengakuisisi melakukan tindakan manajemen laba sebelum pelaksanaan akuisisi dengan metode discretionary accrual. Berdasarkan penghitungan nilai discretionary accrual sebelum akuisisi lebih besar dibandingkan penghitungan setelah akuisisi, namun ada satu perusahaan yang menjelang akuisisi dan setelah akuisisi nilai total akrualnya cenderung bernilai negatif.

Kinerja keuangan perusahaan pengakuisisi sebelum dan setelah perusahaan melakukan akuisisi adalah berbeda dan lebih ke arah penurunan ki-nerja keuangan. Perusahaan tidak selamanya me-lakukan manajemen laba melalui diskresional 
akrual menjelang perusahaan melakukan akuisisi. Hal ini menentang teori yang telah dikemukakan oleh Jones bahwa perusahaan menggunakan total akrual sebagai sumber manipulasi laba untuk mencapai tingkat laba yang positif. Perbedaan kinerja keuangan juga menjadi hasil akhir dari penelitian ini yang membuktikan bahwa kinerja keuangan perusahaan pengakuisisi berbeda lebih ke arah menurunnya kinerja keuangan.

\section{DAFTAR PUSTAKA}

Aida, Ainur Mardiyah.2006. Teori Akuntansi Konsep dan Empiris Edisi 2.Malang: STIE Malang Kucecwara.

Agus, Sartono.1994. Manajemen Keuangan Teori dan Aplikasi Edisi 4: Yogyakarta.BPFE

Anisa, Metta.2008.Analisis Manajemen Laba Perusahaan Sebelum Merger. Universitas Diponegoro. Skripsi

Hadri Kusuma dan Udiana Sari. (2003), Manajemen Laba oleh Perusahaan Pengakuisisi Sebelum Merger dan Akuisisi.Jurnal Ekonomi Vol.7

Igan Budiasih.2006.Faktor-Faktor yang Mempengaruhi Perataan Laba.Jurnal Keuangan 2007 Vol 2

Jordan,Ross \& Westerfield. 2009.Pengantar Keuangan Perusahaan,Jakarta. Salemba Empat
Lukas Setia Atmaja.2003.Manajemen Keuangan Edisi Revisi,Yogyakarta:Andi Lukman Syamsudin.1994.Manajemen Keuangan Perusahaan,Jakarta: PT Raja Grafindo Persada

Marcel, Go.1992. Akuisisi Bisnis Analisis dan Pengelolaan,Jakarta:PT.Rineka Cipta

Martono \& Agus Harjito.2005.Manajemen Keuangan, Yogyakarta:Ekonisia

Mudrajad, Kuncoro.2003.Metode Riset Untuk Bisnis dan Ekonomi,Jakarta:Erlangga

Muhammad, Ma'ruf.2006.Analisis FaktorFaktor yang Mempengaruhi Manajemen Laba. Skripsi Universitas Diponegoro.2006 Nanang, Martono.2010.Metode Penelitian Kuantitatif,Jakarta:PT Raja Grafindo Persada

Pascasarjana UMM.2010.Pedoman Penulisan Artikel Ilmiah,Tesis dan Disertasi, Malang: PPS Universitas Muhammadiyah Malang.

Singgih, Santoso.2002.SPSS.Jakarta. Elek Media Komputindo

Sugiyono.2002.Metode Penelitian Bisnis. Bandung.Alfabeta

Warsono. 2002. Manajemen Keuangan Perusahaan. Malang.UMM Press.

Wirawan, Gerianta \& I Putu Adnyana.2000.Analisis Manajemen Laba dan Kinerja Keuangan Perusahaan Pengakuisisi.Jurnal ekonomi Vol 7

Yopie, Jusuf.2008.Analisis Kredit untuk Account Officer,Jakarta:PT.Gramedia Pustaka Utama 